\title{
ACCELERATING EFFECT OF ARGININE ON THE DEVELOPMENT OF CYTOPHATIC EFFECT OF ADENO VIRUS
}

\author{
TAKEO UEDA, * SHIGESHI TOYOSHIMA and YOSHIKO SETO \\ Pharmaceutical Institute, School of Medicine, Keio University \\ Tokyo, Japan
}

(Received for Publication September 2, 1963)

Schleisinger and his workers ${ }^{(1)}$ reported that plaques of adeno type-2 virus were developed, when the Eagle's medium enriched with arginine was employed as the basal medium of agar-overlay medium, in $\mathrm{KB}$ cells. The present authors (2) also found that arginine showed the accelerating effect on the cytophatic effect (CPE) of adeno virus in Hep. No. 2 cells.

The mechanism of the "Arginine Effect," however, has not been solved throughly yet. This paper concerns with the experiments to make the mechanism of “Arginine Effect” clear.

\section{MATERIALS AND METHODS}

Host cells: Both of $\mathrm{KB}$ and Hep. No, 2 cells were used.

Viral materials: Type-1, 2, 5 and 6 strains of adeno virus were employed. These viral materials were used in the experiments after the several passages in KB cells or Hep. No. cells.

Media: For the growth medium, the YLE $(1.0 \mathrm{~g}$ of yeast extract and $5.0 \mathrm{~g}$ of lact-albumine hydrolysate in $1,000 \mathrm{ml}$ of Earl's balanced salt solution) supplemented with $15 \%$ bovine serum was used throughout the experiments. 100 units per $\mathrm{ml}$ of penicillin and $50 \mathrm{\gamma}$ per $\mathrm{ml}$ of streptomycin were added into the medium. For the maintenance medium, the YLE medium supplemented with 5\% horse serum was used in the most experiments, but in some particular experiments the following special media were employed; a) LE medium $(0.5 \%$ lact-albumin containing Earl's medium) added with $10 \%$ horse serum; b) LH medium (0.5\% lact-albumin containing Hanks' balanced salt solution) supplemented with $\mathbf{5 \%}$ horse serum; c) Eagle's medium supplemented with $15 \%$ horse serum and d) YLA medium, the glucose-content of which was 4.5 times more than that of YLE medium, supplemented with $5 \%$ horse serum.

\footnotetext{
* Professor of Pharmaceutical Institute.
} 
General procedures: The stationary cell-culture technique was employed. One $\mathrm{ml}$ of host cells, $2 \times 10^{5}$ cells $/ \mathrm{ml}$, were added to each assay tube. These assay tubes were incubated at $37^{\circ} \mathrm{C}$ for four days to obtain a monolayer cell sheet. After the establishment of the sheet, the culture fluid of each tube was removed, and the cell sheet was washed three times with phosphate buffered saline (PBS), and then they were ready for use in the experiments.

The detailed description of the experimental procedures will be given in each of the following experimental results sections.

Arginine: Arginine hydrochloride was employed. As described in the preceding paper, the maximum non-toxic does of 1-arginine hydrochloride on both of $\mathrm{KB}$ and Hep. No. 2 cells was $150 \mathrm{\gamma} / \mathrm{ml}$ and $175 \mathrm{\gamma} / \mathrm{ml}$, respectively. Therefore, arginine was used at the final concentration of $150 \mathrm{\gamma} / \mathrm{ml}$ in the experiments using the Hep. No. 2 cell and of $100 \mathrm{\gamma} / \mathrm{ml}$ in the $\mathrm{KB}$ employing experiments.

\section{EXPERIMENTAL RESULTS}

1: The Effect of Arginine on the Development of Cytophatic Effect of Several Types of Adeno Virus in Hep. No. 2 and KB Cells.

Shleisinger(1) reported that adeno type-2 strain showed the sensitivity on "Arginine effect," but no report as to the effect of arginine on the development of plaques of the other types of adeno virus has been found yet, and the preceding report(2) of the authors also was of the results of the experiments by using type-2 of adeno virus. Thus, it may be said that the type-specificity of adeno virus on "Arginine Effect" has not been solved yet. To clarify this point, the following experiments were carried out.

$0.9 \mathrm{ml}$ of arginine-rich YLE medium supplemented with $5 \%$ horse serum was added to tubes in which the monosheet of the Hep. No. 2 cell had been established, and immediately after, these tubes were inoculated with various dilutions of each of tested viral strains. Then, they were incubated at $37^{\circ} \mathrm{C}$ for 21 days and the TCID 50 (tissue culture infective dosis fifty) of each of the treated and the control groups was plotted. For the control group, the same amount of PBS instead of arginine solution was added into medium. The exchange of the maintenance medium was carried out every seven days.

The experimental results are shown in Table 1.

As can be seen in Table 1, in the groups incubated by using the arginine rich medium, the TCID 50 of all of employed viral strains was rised more quickly than that of them in the control groups.

In both of KB and Hep. No. 2 cells, the "Arginine Effect" was clearly recognized on not only type 2 virus but other employed strains such as type 1, 5 and 
Table 1.

Accslerating Effect of Arginine on Drvelopment of Cytophatic Effect of Adeno Virus

\begin{tabular}{|c|c|c|c|c|c|c|c|c|c|c|c|c|c|c|c|c|}
\hline \multirow{4}{*}{$\begin{array}{c}\text { Days after } \\
\text { inoculation } \\
\text { (days) }\end{array}$} & \multicolumn{16}{|c|}{$\operatorname{TCID}_{50}\left(-\mathrm{Log}_{.}\right)$} \\
\hline & \multicolumn{8}{|c|}{ in $\mathrm{KB}$ cells } & \multicolumn{8}{|c|}{ in Hep.No.2 cells } \\
\hline & \multicolumn{2}{|c|}{ Type-1 } & \multicolumn{2}{|c|}{ Type--2 } & \multicolumn{2}{|c|}{ Type-5 } & \multicolumn{2}{|c|}{ Type- 6} & \multicolumn{2}{|c|}{ Type-1 } & \multicolumn{2}{|c|}{ Type-2 } & \multicolumn{2}{|c|}{ Type-5 } & \multicolumn{2}{|c|}{ Type-6 } \\
\hline & $\begin{array}{c}A_{1} \\
(+)\end{array}$ & $\mathrm{A}_{2}$ & $\begin{array}{c}A \\
(+)\end{array} \mid$ & $\left(\begin{array}{l}\bar{A} \\
(-)\end{array}\right.$ & $\begin{array}{c}\mathrm{A} \\
(+)\end{array}$ & $\left(\begin{array}{c}\mathrm{A} \\
(-)\end{array}\right.$ & $\begin{array}{c}A \\
(+)\end{array}$ & $\begin{array}{c}A \\
(-)\end{array}$ & $\begin{array}{l}\text { A } \\
+ \text { ) }\end{array}$ & $\begin{array}{c}A \\
(-)\end{array}$ & $\begin{array}{c}\mathrm{A} \\
(+)\end{array}$ & $\left.\mid \begin{array}{c}\mathrm{A} \\
(-)\end{array}\right)$ & $\begin{array}{c}A \\
(+)\end{array}$ & $\left|\begin{array}{c}A \\
(-)\end{array}\right|$ & $\left|\begin{array}{c}\mathrm{A} \\
(+)\end{array}\right|$ & $\begin{array}{c}A \\
(-)\end{array}$ \\
\hline 2 & & & & & 3 & 2 & & & 3.5 & 3.5 & 3.5 & 2.5 & & & 3 & 1.5 \\
\hline 3 & & & & & 3.5 & $\overline{2.5}$ & 3 & 3 & 4 & 4 & 5 & 4 & 3.5 & 3.5 & 5 & 4 \\
\hline 4 & 3.5 & 3.5 & 3.5 & 3.5 & 4 & 3 & 4 & 3.5 & 4.5 & $\overline{4.5}$ & 5.5 & $\overline{4.5}$ & 5.5 & 4 & 5.5 & 4.5 \\
\hline 5 & 4 & 3.5 & 4.5 & 3.5 & 5 & 4 & 5 & 4 & 5 & 4.5 & 6 & 4.5 & 5.5 & 5.5 & 5.5 & 4.5 \\
\hline 6 & 6.5 & 5 & 5.5 & 3.5 & 6 & 4.5 & 6 & 4.5 & 5.5 & 4.5 & 6 & 4.5 & 6 & 5.5 & 6 & 4.5 \\
\hline 7 & & & 6 & 4.5 & & & & & 6 & 4.5 & 6.5 & 4.5 & 6.5 & 5.5 & & \\
\hline 8 & 7 & 6 & 6.5 & 5 & 6.5 & 5 & 6.5 & 4.5 & 6.5 & 5 & 7 & 4.5 & 7 & 5.5 & 6.5 & 5 \\
\hline 9 & & & & & 7 & 5 & & & 6.5 & 5.5 & 7 & 5 & 7.5 & 6 & 6.5 & 5 \\
\hline 10 & 7.5 & 6.5 & 8 & 7 & & & 7 & 5.5 & 7 & 5.5 & 8 & 5.5 & 7.5 & 7 & 7 & 5.5 \\
\hline 11 & 8 & 8 & 8 & 7 & 8.5 & 7 & 7.5 & 7 & 8 & 6.5 & 8.5 & 6 & 7.5 & 7.5 & 8 & 6 \\
\hline 12 & 8.5 & 8 & 8 & 7 & & & 7.5 & 7 & 9 & 8 & 9 & 7 & 7.5 & 7.5 & & \\
\hline 13 & & & 8 & 7 & & & & & 9 & 8 & 9 & 7 & 8 & 8 & 8.5 & 7 \\
\hline 14 & 9 & 8.5 & 8 & 7 & 9 & 7.5 & 8 & $\overline{7.5}$ & & & 9 & 7 & $\overline{8}$ & 8 & 8.5 & 7 \\
\hline 15 & & & 8 & 7 & & & 8 & 7.5 & 9 & 8 & 9 & 8 & 8 & 8 & & \\
\hline 16 & & & 8 & 7 & 9 & 7.5 & 8 & 7.5 & & & 9 & 8.5 & 8 & 8 & 8.5 & 7 \\
\hline 21 & 9 & 8.5 & 8 & 7 & 9 & 8 & 8 & 7.5 & 9 & 8 & 9 & 9 & 8 & 8 & 8.5 & 7.5 \\
\hline
\end{tabular}

$\mathrm{A}_{1} .100 \mathrm{\gamma} / \mathrm{ml}$ of arginine was supplemented into the medium in the expe:imerts using $\mathrm{KB}$

$(+)$ : cells and $150 \gamma / \mathrm{ml}$ of arginine was added into the medium in the culture using Hep. No. 2 cells.

$(-)$ : The ordinary medium without any addition of arginine was used.

type 6 of adeno virus.

From the experimental results, its may be said that the "Arginine Effect" on the development of CPE of adeno virus is not of type-specificity.

2: Interaction between the Changes of $\mathrm{pH}$ in Media and the Appearance of "Arginine Effect."

It was reported by several in investigators ${ }^{(3)}$ that the marked accumulation of such organic acids as lactic acid and so on in the culture fluid and the fall of 
$\mathrm{pH}$ of the fluid were found with along the intracellular viral multiplication after the infection of adeno virus. Therefore, it can be assumed easily that the production of such organic acids in the cell culture infected with adeno virus might be accelerated by adding of arginine and then the quick development of the CPE might be resulted in. To clarify this problem, the following experiments were carried out.

$0.9 \mathrm{ml}$ of each of the employed media of YLA, LH, LE and Eagle's, all of which were supplemented with horse serum at the amount as described in the section of "Materials and Methods" and with $150 \mathrm{\gamma} / \mathrm{ml}$ of arginine, was added into assay-tubes, in which the monosheet of the Hep. No. 2 cell had already been established, and soon later $0.1 \mathrm{ml}$ of $10^{-2}$ dilution of type 2 strain of adeno virus was inoculated into the tubes. For the control, each of corresponding ordinary media without any supplement of arginine was used.

The experimental results are shown in Table 2.

Table 2.

Interaction between Arginine Effect and PH of Culture Fluid

\begin{tabular}{|c|c|c|c|c|c|c|c|c|c|}
\hline \multirow{2}{*}{ Employed media } & \multicolumn{8}{|c|}{$\mathrm{pH}$ of culture fluid Days after viral inoculation } & \multirow[b]{2}{*}{$\mathrm{CPE}^{\mathrm{a}}$} \\
\hline & 0 & 1 & 2 & 3 & 4 & 5 & 6 & 7 & \\
\hline 5 HSYLA 1 & 7.5 & 7.2 & 7.1 & 7.1 & 6.8 & 6.5 & 6.5 & 6.5 & 7 \\
\hline 5 HSYLA + Arginine ${ }^{2}$ & 7.5 & 7.2 & 7.2 & 7.1 & 6.8 & 6.5 & 6.5 & 6.5 & 6 \\
\hline $5 \mathrm{HSLH}^{3}$ & 7.3 & 6.9 & 6.9 & 6.9 & 6.6 & 6.5 & 6.5 & 6.5 & 7 \\
\hline 5 HSLH + Arginine & 7.3 & 6.9 & 6.8 & 6.7 & 6.6 & 6.7 & 6.7 & 6.8 & 6 \\
\hline $10 \mathrm{HSLE}^{4}$ & 7.4 & 7.0 & 7.1 & 71 & 7.1 & 7.1 & 7.1 & 7.1 & 5 \\
\hline $10 \mathrm{HSLE}+$ Arginine & 7.4 & 7.1 & 7.0 & 7.0 & 7.1 & 7.1 & 7.1 & 7.1 & 4 \\
\hline 15 Eagle's ${ }^{5}$ & 7.5 & 73 & 7.4 & 7.4 & 75 & 7.4 & 7.5 & 7.5 & 6 \\
\hline 15 Eagle's + Arginine & 7.5 & 7.2 & 7.3 & 7.3 & 7.4 & 7.5 & 7.5 & 7.5 & 4 \\
\hline
\end{tabular}

Type 2 virus and Hep.No.2 cells were employed.

5 HSYLA $^{1}$ : YLA medium supplemented with $5 \%$ horse serum.

Arginine ${ }^{2}: 150 \gamma / \mathrm{ml}$ of arginine was added in arginine rich group.

$5 \mathrm{HSLH}^{3}$ : LH medium supplemented with $5 \%$ horse serum.

$10 \mathrm{HS} \mathrm{LE}^{4}$ : LE medium supplemented with $10 \%$ horse serum.

15 Eagle's $^{5}$ : Eagle's medium supplemented with $15 \%$ horse serum.

$\mathrm{CPE}^{6}$ : The first day of the development of cytophatic effect.

As can be shown in Table 2, no remarkable difference between the fall of $\mathrm{pH}$ of the culture fluid of the treated groups and that of the control was observed, and moreover in the groups using the LE-and Eagle's media as the basal medium, the fall of $\mathrm{pH}$ of the culture fluid even after the intracellular increase of the virus was not found. These findings suggest that the possibility of the direct interaction between the fall of $\mathrm{pH}$ of the culture fluid and the appearance of "Arginine 
Effect" may be ruled out.

3: The Effect of Arginine on the Multiplication and the Release of Adeno Virus.

It is a well-known fact(4) that the viral amount of all types of adeno virus released from cells into culture fluid is very poor and the almost virus is still in a cell-associated condition even after the clear intracellular increase of the virus. The poor release of the virus from cells may be one of the mechanisms of the slow appearance of the cytophatic effect. In the preceding report of the authors (2) and in the above description, the quick development of CPE of adeno virus was clearly observed in the groups supplemented with arginine. Thus, it may be assumed that the intracellular multiplication of adeno virus might be prompted by adding of arginine and moreover the release of the virus from cells into culture fluid might be greater in the groups supplemented with arginine than that of the control. To clarify these problems, the following experiments were carried out. $0.9 \mathrm{ml}$ of arginine rich Eagle's medium or the ordinary same medium, which were supplemented with $15 \%$ horse serum, was added into tubes in which the monosheet of the Hep. No. 2 cell had been established, and after that, the type-1 and the type-2 strains of adeno virus were inoculated respectively to these tubes at an infectious multiplicity of 1 per cell. Then the tubes were incubated at $37^{\circ} \mathrm{C}$ for two hours. The medium was removed from each of these tubes, and the cellsheet was washed three times with PBS to remove unadsorbed virus. Fresh maintenance medium was added into these tubes again, and they were further incubated. At 48 hours and 72 hours after the viral inoculation, the culture fluid

Table 3.

Stimulating Effect of Arginine on Multiplication and Release of Adeno Virus

Type 1 and type 2 viruses Hep. No. 2 cells Eagle's medium supplemented with 15\% horse se:um was employed. In arginire rich group, $150 \gamma / \mathrm{ml}$ cf arginine was added.

\begin{tabular}{|c|c|c|c|c|c|c|c|}
\hline \multirow{3}{*}{\multicolumn{2}{|c|}{ Types of employed virus }} & \multicolumn{6}{|c|}{$\mathrm{TCID}_{50}(-\mathrm{Log})}$. \\
\hline & & \multicolumn{6}{|c|}{ Days after inoculation } \\
\hline & & \multicolumn{3}{|c|}{2} & \multicolumn{3}{|c|}{3} \\
\hline \multirow{3}{*}{ Type 1} & \multirow{3}{*}{$\begin{array}{l}\text { Control } \\
\text { Arginine rich }\end{array}$} & $\mathrm{CV}$ & $\mathrm{R}^{2}$ & $\stackrel{3}{\mathrm{R}}$ & $\mathrm{CV}$ & RV & $\mathrm{R}$ \\
\hline & & 5 & 3.5 & 1.4 & 6.25 & 3.5 & 1.7 \\
\hline & & 6.5 & 3.5 & 1.8 & 8.0 & 4.5 & 1.7 \\
\hline \multirow{2}{*}{ Type 2} & Control & 4.0 & 2.5 & 1.6 & 6.0 & 3.0 & 2.0 \\
\hline & Arginine rich & 6.5 & 3.5 & 1.8 & 7.5 & 3.5 & 2.1 \\
\hline
\end{tabular}

CV : Cell-associated virus.

$\mathrm{RV}^{2}$ : Released virus.

$\stackrel{3}{R}$; Ratio of relẹased vịus divịided by cell-ạssociagted yirus, 
was removed from each of the tubes, and the cellsheet was washed three times with the ordinary Eagle's medium. The washings and the removed culture fluid were joined together, and the mixture was centrifuged at 3000 rpm for ten minutes. The supernatant was employed for the material of the assay of released viral amount. The cells were scrapped off with a rubber policeman into the ordinary Eagle's medium, and the centrifuged pellets of the mixture of the washings and the culture fluid were further added to the cell-suspension. The suspension was frozen and thawed five times, and then it was centrifuged at $3000 \mathrm{rpm}$ for ten minutes. The supernatant was employed for the assay of cell-associated virus.

The experimental results are shown in Table 3.

As can clearly be shown in Table 1 , the TCID $_{50}$ of both of the cell-associated virus and the released one in the arginine rich group was higher than that of the control group, in which the ordinary Eagle's medium was employed. The ratio of the released virus divided by the cell-associated virus in the arginine rich group was smaller than that of the control. Thus, it may be said that arginine remarkably promotes the multiplication of adeno virus, but not the release of the multiplied virus from cells. The fact suggests that "Arginine Effect". might be caused by the stimulation of the intracellular multiplication of adeno virus.

4: The Accelerating Effect of Arginine Related Compounds on The Developemnt of The Cytophatic Effect of Adeno Virus.

The results obtained in the above experiments led the authors question the problem why the intracellular multiplication of adeno virus was accelerated by the addition of arginine.

Arginine is one of the important intermediates in the Ornithine-cycle. So, it may be assumed that the addition of arginine might stimulate the activity of Ornithine-cycle, and, as a result the multiplication of the virus might be promoted. If this assumption were the case, some of the intermediates in Ornithine-cycle aIso might show the similar effect to "Arginine Effect." To solve this problem, the following experiments were carried out.

$0.8 \mathrm{ml}$ of LE medium was added into tubes in which the monosheet of the Hep. No. 2 cell had been established, and after that $10^{-3} \mathrm{M}$ of ornithine, citrulline, urea and arginine were added into tubes in a volume of $0.1 \mathrm{ml}$, respectively, and immediately later, $0.1 \mathrm{ml}$ of $10^{-4}$ dilution of type-2 strain of adeno virus was inoculated. Then, these tubes were incubated at $37^{\circ} \mathrm{C}$ for 6 days. These tubes were observed microscopicaly, and the development of the cytophatic effect was recorded as follows;

0 : No cytophatic effect.

1: CPE was observed in about twenty-five percent of objective field, 
2: CPE was observed in about fifty percent of objective field.

3: CPE was observed in about seventy-five percent of objective field.

4: Complete cell-degeneration.

The experimental results are shown in Table 4.

Tabel 4.

Accelerating Effect of Arginine and Its Homologues on Development of Cytophatic Effect of Adeno Virus

\begin{tabular}{|c|c|c|c|c|c|c|c|}
\hline & \multicolumn{7}{|c|}{$\begin{array}{c}\text { Score of CPE } \\
\text { Days after viral inoculation }\end{array}$} \\
\hline & 1 & 2 & 3 & 4 & 5 & 6 & Remarks \\
\hline Control ${ }^{1}$ & 0 & 0 & 0.25 & 1.5 & 2.5 & 3.5 & \\
\hline Arginine rich $^{2}$ & & 2 & 3.5 & 4 & & & Average value \\
\hline Ornithine rich $^{3}$ & 1 & 1.5 & 2.5 & 2.5 & 3 & 3.5 & $\begin{array}{l}\text { of four assay } \\
\text { tubes. }\end{array}$ \\
\hline Citrulline rich $^{4}$ & 0 & 0 & 0.25 & 2 & 2.5 & 3.5 & \\
\hline Urea rich ${ }^{5}$ & 0 & 0 & 0 & 0.5 & 1 & 2.5 & \\
\hline
\end{tabular}

Type 2 virus and Hep. No. 2 cells were employed.

LE medium supplemented with $5 \%$ horse serum was used as a basal medium, and $10^{-3} \mathrm{M}$ of each of tested compounds was added into the basal medium.

Control $^{1}$ : The group without any addition of drugs.

Arginine rich ${ }^{2}$ : The group supplemented with $10^{-3} \mathrm{M}$ of arginine.

Ornithine rich ${ }^{3}$ : The group supplemented with $10^{-3} \mathrm{M}$ of ornithine.

Citrulline rich ${ }^{4}$ The group supplemented with $10^{-3} \mathrm{M}$ of citrulline.

Urea rich ${ }^{5}$ : The group supplemented with $10^{-3} \mathrm{M}$ of urea.

As shown in Table 4, the progress of CPE in the arginine rich group was the quickest among the tested groups, and the second was observed in the group treated with ornithine, but the other two groups treated with citrulline or urea did not show any accelerating effect on the development of CPE. The effect of ornithine was not so great as arginine showed. Thus, the results suggest that the intermediates of Ornithine-cycle except arginine do not participate to the appearance of "Arginine Effect," and the accelerating effect of arginine on the development of $\mathrm{CPE}$ and the multiplication of adeno virus might be caused by a specific effect of arginine.

\section{DISCUSSION}

The slow development of the cytophatic effect of adeno virus has given researchers difficulty to carry out the minute and quick assay of the virus. Schleisinger(1) and our group(2) showed that arginine accelerated the production of the cell degeneration due to the infection of adeno virus in the Hep. No. 2 celltype 2 virus system. KB cells also could be used as a suitable cell-line instead of the Hep. No, 2 cell. The mẹhanism of "Arginine Effect," however, has not been 
clarified yet. Upto now, the type 2 strain of adeno virus only has been employed in the studies on "Arginine Effect," and so it has not been clarified whether this effect is of viral type-specificity or not. As shown in experimental results, the effect was observed in the experiments by using four strains such as type 1, type 2, type 5 and type 6 of adeno virus. Therefore, it may be said that "Arginine Effect" is not of viral type-specificity. These results suggest that arginine gives a stimulating effect on some essential point for the multiplication or the development of the cytophatic effect of adeno virus. It is a well-known fact that the accumulation of organic acids was observed in culture fluid of the cells infected with adeno virus, and the lowering of $\mathrm{pH}$ due to the accumulation of acids should play an important part in the development of the cytophatic effect of the virus. Thus, it was assumed that arginine might stimulate the production of organic acids and as the results it might accelerate the development of the cytophatic effect of the virus. The experimental results, however, denied this possibility, because "Arginine Effect" was clearly observed though the lowering of $\mathrm{pH}$ of the culture fluid due to the addition of arginine could not be found.

In general, adeno virus shows the clear and quick intracellular multiplication, but almost of the multiplied viral particles do not release from host cells. Such a cell-associated condition of adeno virus should be the main origin of the slow development of the cytophatic effect of the virus. Thus, it may be assumed that arginine might stimulate the release of virus from host cells, and it might accelerate the quick production of the cytophatic effect of the virus. As can be seen in the experimental part, in fact, the release of adeno virus from host cells was remarkably accelerated by the addition of arginine. But the ratio of released viral amount/cell-associated viral amount was not always greater than that of the control group. These findings suggest that the increase of the released viral amount should not be due to the accelerating effect of arginine on the viral release from host cells. In spite of the addition of arginine, the viral release from host cells did not show any increase in the degree and the rate compared with those of the control group. Thus, it may be said that the essential mechanism of "Arginine Effect" should not be in the viral release. The increase of the released viral amount should be the secondary phenomenon of the remarkable intracellular multiplication of adeno virus due to the addition of arginine. Arginine should give some stimulating effects on the multiplication of adeno virus in intracellular sites and as the results both of the absolute amount of released virus and the quick development of the cytophatic effect should be introduced.

Arginine is one of the important intermediates in Ornithine-cycle. Thus, it may be assumed that the addition of arginine might cause the increase of the 
activity of this cycle, and the effect might give the stimulating effect on the multiplication of adeno virus. The other intermediates such as ornithine, citrulline and urea didi not show so remarkable stimulation on the development of the cytophatic effect of adeno virus as arginine did. These findings suggest that the "Arginine Effect" should be caused by a specific effect of arginine on the intracellular multiplication-mechanism of adeno virus.

The search to solve this specific effect of arginine is in progress. The experimental results will be reported in the next publication in the near future.

\section{SUMMARY}

In both of Hep. No. 2 and $\mathrm{KB}$ cells, arginine remarkably accelerated the development of the cytophatic effect of the type 2 strain of adeno virus. This effect, "Arginine Effect," was observed in not only type 2 virus but other strains such as type 1 , type 5 and type 6 strains of adeno virus. The acceleration of the lowering of $\mathrm{pH}$ of culture fluid of the cells infected with adeno virus in the arginine rich group was not found. The stimulation of arginine on the degree and the rate of the viral release from host cells also was not found. In the group riched with arginine, the clear increase of the intracellular multiplication of adeno virus was observed. Thus, it may be considered that the main mechanism of "Arginine Effect" should be in the multiplication-mechanism of adeno virus in intracellular site. This mechanism is not of the stimulation of the activity of Ornithine-cycle, but of some specific effect of arginine on the replication-mechanism of adeno virus particles.

\section{REFERENCES}

1.a) Bonifas, V. and Schleisinger, R. W.: Nutritional requirements for plaque production by adeno virus, Red. Proc., 18: 560, 1959.

b) Schleisinger, R. W.: Vagaries of adeno virus-cell complex. Perspectives in virology, II: 69. 1961.

2. Ueda, T., Toyoshima, S., and Seto, Y.: The accelerating effect of arginine on cytophatic effect of adeno virus. Chem. and Pharm. Bull., 11: 1, 1963.

3.a) Ginsberg, H. S.: Characteristics of the new respiratory viruses (Adeno virus). II. Stability to temperature and $\mathrm{pH}$ alternation. Proc. Soc. exp. Biol. and Med., 93: 48.1956.

b) Houebner, R. L. ,Rowe, W. P. and Chanock, R. M.: Newly recognized respiratory tract viruses. Ann. Rev. of Microbiol., 12: 49, 1958.

c) Fisher, T. N. and Ginsberg, H. S.: Accumulation of organic acids by HeLa cells infected with type 4 adeno virus. Proc. Soc. exp. Boil. and Med., 95: 47, 1957.

4. Dingle, J. H. and Ginsberg, H. S.: The adeno virus group, Viral and Rickettsial Infections of Man. p-619, 1959. 